\title{
The potential of replacing conventional dairy supplements with forage legume-based diets in Zimbabwe's smallholder dairy sector
}

Lovemore C Gwiriri, Godfrey Manyawu, Promise B Mashanda, Irenie Chakoma, Siboniso Moyo, Charles Chakoma, Hazel Sethaunyane, Venancio E Imbayarwo-Chikosi, Sikhalazo Dube \& Barbara V Maasdorp

To cite this article: Lovemore C Gwiriri, Godfrey Manyawu, Promise B Mashanda, Irenie Chakoma, Siboniso Moyo, Charles Chakoma, Hazel Sethaunyane, Venancio E Imbayarwo-Chikosi, Sikhalazo Dube \& Barbara V Maasdorp (2016) The potential of replacing conventional dairy supplements with forage legume-based diets in Zimbabwe's smallholder dairy sector, African Journal of Range \& Forage Science, 33:3, 155-163, DOI: 10.2989/10220119.2016.1170727

To link to this article: http://dx.doi.org/10.2989/10220119.2016.1170727

曲 Published online: 22 Jul 2016.

Submit your article to this journal $\pi$

Щ Article views: 33

Q View related articles 준

View Crossmark data $\nearrow$ 


\title{
The potential of replacing conventional dairy supplements with forage legume-based diets in Zimbabwe's smallholder dairy sector
}

\author{
Lovemore C Gwiriri', Godfrey Manyawu', Promise B Mashanda², Irenie Chakoma', Siboniso Moyo³, Charles Chakoma ${ }^{4}$, \\ Hazel Sethaunyane ${ }^{5}$, Venancio E Imbayarwo-Chikosi ${ }^{2}$, Sikhalazo Dube ${ }^{1}$ and Barbara V Maasdorp ${ }^{6}$ \\ 1 International Livestock Research Institute, c/o CIMMYT Southern Africa Regional Office, Harare, Zimbabwe \\ 2 Department of Animal Science, University of Zimbabwe, Harare, Zimbabwe \\ ${ }^{3}$ International Livestock Research Institute, Addis Ababa, Ethiopia \\ ${ }^{4}$ Independent, Harare, Zimbabwe \\ ${ }^{5}$ Chikwaka-Kubatana Dairy Co-operative, Juru Growth Point, Arcturus, Zimbabwe \\ ${ }^{6}$ Department of Crop Science, University of Zimbabwe, Harare, Zimbabwe \\ *Corresponding author, email: luvgwiriri@yahoo.com, gwiriril@uni.coventry.ac.uk
}

\begin{abstract}
The effect of replacing commercial supplements with isoenergetic and isonitrogenous velvet bean-, cowpeaand lablab-based supplements on milk yield, milk quality and economic returns in smallholder crossbred dairy cows was investigated in the 2013 and 2014 dry seasons. Using $3 \times 3$ Latin square designs, nine multiparous Red Dane, Guernsey and Holstein-Friesian crosses in mid-lactation (130 $\pm 19 \mathrm{~d}$ ) were offered forage legume-based supplements for $63 \mathrm{~d}$ at $0.5 \mathrm{~kg}$ per litre of milk produced. Milk quantity and quality were significantly $(P<0.05)$ different among supplements in both seasons. Cows fed commercial supplements had higher milk yield than cows fed forage legume supplements. Milk fat content was significantly $(p<0.05)$ higher in cows fed lablabbased supplements than cows fed other supplements. Milk protein, total solids and lactose content of cows fed commercial supplements was significantly $(p<0.05)$ higher than those fed forage legume-based supplements, although protein content was similar to cows fed lablab-based supplements. Dietary gross margins were higher for cows fed velvet bean- and lablab-based supplements by $17 \%$ and $16.5 \%$, respectively. Based on supplement, production costs per litre of milk was higher by $28 \%$ and $23 \%$ using commercial supplements compared to velvet bean and lablab supplements, respectively.
\end{abstract}

Keywords: forage legumes, smallholder dairy, Zimbabwe

\section{Introduction}

Several authors have projected an increase in demand for food and food products with an increase in population by 2050 (Thornton and Herrero 2010; Gerber et al. 2013; Ross et al. 2014). Smallholder farmers in Zimbabwe currently contribute only $1-2 \%$ to national milk production (Chinogaramombe et al. 2008; Manyawu et al. 2013). This leaves a huge gap where the current national annual milk demand in Zimbabwe is 120 million litres against a current annual milk production of 56 million litres (Department of Livestock Production and Development 2014). Therefore, there is scope for smallholder farmers to improve productivity to meet this demand and invariably improve rural household income and livelihoods through inclusion in local and regional value chains.

Various authors have documented the shrinkage of the dairy sector in Zimbabwe and the declining trend in milk production from 262 million litres (1990), through 187 million litres (2000) to 37 million litres (2009) owing to a number of challenges (Department of Livestock Production and Development 2011; Osman 2014). Challenges limiting dairy development in Zimbabwe's smallholder dairy sector include herd size and herd productivity decline, poor genetic quality and access, high disease prevalence, poor management practices and lack of skilled personnel, and poor quality and high cost of feed (Ngongoni et al. 2006).

Nutrition remains one of the major constraints to smallholder dairy production. Several authors (Moran 2005; Mapiye et al. 2007; Mapekula et al. 2009; Madzimure et al. 2011) concur that lack of protein, especially during the dry season, limits smallholder dairy performance. According to Oleredi and Ajay (2005) and Chinogaramombe et al. (2008), low nutritive value of available feed resources and resultant reduced efficiency of utilisation account for the reduced dairy performance. Work by Murungweni et al. (2004) has demonstrated that forage legumes such as Mucuna pruriens var. utilis (velvet bean), Vigna unguiculata (cowpea) and Lablab purpureus (lablab) can potentially replace commercial concentrates in dairy diets.

Strategies to improve smallholder dairy productivity and market competitiveness are underpinned by increasing milk quality and quantity via efficient feed utilisation and availability at a considerably lower cost. Arriaga-Jordán et al. (2002) and García-Martínez et al. (2009) reported in Mexico that small-scale farmers have acknowledged the need for better and sustainable feeding strategies to improve the performance of their herds. Gusha et al. (2013) allude to the 
fact that farm income can be optimised by utilising low-cost and more available feed resources whilst maintaining the quantity and quality of milk produced. Livestock genetic and feed manipulation to improve dairy performance can be a viable option to meet the growing milk demand.

Conventional feed meals and protein supplements, such as sunflower, groundnut and cottonseed cakes or meals, are not readily available and are generally expensive (Chinogaramombe et al. 2008). Use of these conventional protein sources by smallholder dairy farmers coupled with other dairy production constraints limits their viability. Therefore, the use of forage legumes, such as velvet bean, cowpea, lablab, and browse legumes, such as acacia (Senegalia and Vachellia), Calliandra and Leucaena tree species, which are adaptable to subhumid and semi-arid tropical regions, could present a viable alternative (Chakeredza et al. 2008; Chinogaramombe et al. 2008; Volpelli et al. 2010). Velvet bean and lablab, which have relatively high crude protein (CP) contents ranging from $16 \%$ to $19 \%$ and are low in fibre, can supplement low-quality roughages to improve productivity of ruminants (Gwanzura et al. 2012). Work by Mashanda (2014) demonstrates the use of velvet bean and cowpea forage legumes to replace commercial concentrate and reduce the production cost of milk by $20 \%$.

The present study is based on the premise that during the drier months of the year, communal rangelands in Zimbabwe, which form the bulk of the feed resource for smallholder farmers, are characterised by poor feed quality and quantity, culminating in smallholder farmers supplementing with commercial supplements. Smallholder dairy farmers often lack capital to purchase commercial dairy supplements resulting in a reduction in milk production during this period. The study was therefore carried out (1) to evaluate the feasibility and effect of replacing commercial dairy supplements with on-farm produced forage-legume supplements on milk quality and quantity and (2) to assess the feed-based economic viability of replacing commercial supplements with forage-legume supplements in smallholder dairy systems. The study aimed to evaluate the feasibility of utilising forage legumes in smallholderproduced on-farm supplements.

\section{Materials and methods}

\section{Study area}

The study was conducted in Zimbabwe's Goromonzi $\left(17^{\circ} 29^{\prime} \mathrm{S}, 31^{\circ} 29^{\prime} \mathrm{E}\right)$ and Murehwa $\left(17^{\circ} 24^{\prime} \mathrm{S}, 31^{\circ} 35^{\prime} \mathrm{E}\right)$ districts, $54 \mathrm{~km}$ and $70 \mathrm{~km}$ north-east of the capital city, Harare, respectively. Murehwa and Goromonzi districts are in the subhumid agro-ecological region $2 \mathrm{~b}$. Agro-ecological region $2 \mathrm{~b}$, which covers $15 \%$ of Zimbabwe, is characterised by an average annual rainfall of 750-1 $000 \mathrm{~mm}$ with 16-18 rainy pentads per season. The rains are confined to summer, received from October to April, whereas the rest of the year is dry. Temperatures range from $10{ }^{\circ} \mathrm{C}$ minimum in June-July to $35{ }^{\circ} \mathrm{C}$ maximum in October-November (Hove et al. 2003). The soils are generally well-drained, highly leached, coarse-grained sand derived from granite. The soils are inherently infertile, classified as fersialitic with very low soil organic carbon, phosphorus, sulphur and nitrogen (Nyamapfene 1991). Studies have indicated that up to $63 \%$ of the soils in this region are generally acidic $(\mathrm{pH}<4.5)$ reducing availability of most macronutrients, falling below the critical marginal threshold of 20-30 ppm nitrogen, $15-30 \mathrm{ppm}$ phosphorus and $0.1-0.2 \mathrm{mg}$ per $100 \mathrm{~g}$ potassium (Mugwira and Nyamangara 1998). The net effect is limited crop productivity where smallholder farmers cannot afford corrective measures.

\section{Treatment diets}

Four isonitrogenous and isoenergetic diets containing $16 \% \mathrm{CP}$ and $12 \mathrm{MJ} \mathrm{kg}^{-1}$ metabolisable energy (ME) (Table 1) were fed to crossbred dairy cows on-farm in the Goromonzi and Murehwa districts of Zimbabwe in a two-step $3 \times 3$ Latin square design. Isonitrogenous and isoenergetic diets are those that have the same amount of dietary nitrogen and energy, respectively. The diets consisted of a commercial supplement, a velvet bean (Mucuna pruriens var. utilis) based diet, a cowpea (Vigna unguiculata 'CBC3') based diet and a lablab (Lablab purpureus 'Highworth') based diet. Lablab and cowpea hay in the diets was made by cutting forage at the booting or early flowering stage, drying for $3-5 \mathrm{~d}$ then bailing. The velvet bean diet also consisted of pods and seeds, as velvet bean is a prolific

Table 1: Treatment diets fed to dairy crossbred animals in the Goromonzi and Murehwa districts, Zimbabwe

\begin{tabular}{|c|c|c|c|c|c|c|c|c|}
\hline \multirow{2}{*}{ Ingredient } & \multicolumn{2}{|c|}{ Velvet bean diet } & \multicolumn{2}{|r|}{ Lablab diet } & \multicolumn{2}{|c|}{ Cowpea diet } & \multicolumn{2}{|c|}{ Commercial diet } \\
\hline & $\%$ & Cost $\left(\right.$ US $\left.\$ \mathrm{~kg}^{-1}\right)$ & $\%$ & Cost $\left(\right.$ US $\left.\$ \mathrm{~kg}^{-1}\right)$ & $\%$ & Cost $\left(\right.$ US $\left.\$ \mathrm{~kg}^{-1}\right)$ & $\%$ & Cost (US\$ kg-1) \\
\hline Maize grain & 25 & 0.10 & 36 & 0.14 & 20 & 0.08 & - & - \\
\hline Lablab hay & - & - & 43 & 0.06 & - & - & - & - \\
\hline Velvet bean grain & 44 & 0.11 & - & - & - & - & - & - \\
\hline Velvet bean pods with grain & 30 & 0.08 & - & - & - & - & - & - \\
\hline Cowpea hay & - & - & - & - & 50 & 0.12 & - & - \\
\hline Vitamin premix & 1 & 0.01 & 1 & 0.01 & 1 & 0.01 & - & - \\
\hline $16 \%$ Dairy meal (Pastulak) & - & - & - & - & - & - & 100 & 0.44 \\
\hline Cost per kg (US\$) & \multicolumn{2}{|r|}{0.30} & \multicolumn{2}{|r|}{0.33} & \multicolumn{2}{|r|}{0.40} & \multicolumn{2}{|r|}{0.44} \\
\hline Dry matter (\%) & \multicolumn{2}{|r|}{88.9} & \multicolumn{2}{|r|}{88} & \multicolumn{2}{|r|}{89} & \multicolumn{2}{|r|}{89} \\
\hline Crude protein $(\%)$ & \multicolumn{2}{|r|}{16.01} & \multicolumn{2}{|r|}{16.02} & \multicolumn{2}{|r|}{15.9} & \multicolumn{2}{|r|}{16} \\
\hline Crude fibre $(\%)$ & \multicolumn{2}{|r|}{12.09} & \multicolumn{2}{|r|}{13.8} & \multicolumn{2}{|r|}{13.5} & \multicolumn{2}{|r|}{12} \\
\hline
\end{tabular}


seed producer, with recordings of over $1.5 \mathrm{t} \mathrm{ha}^{-1}$ (Maasdorp et al. 2004). The CP content range of lablab hay, cowpea hay, velvet bean seeds and velvet bean pods with seed was $11-12 \%, 13-15 \%, 20-22 \%$ and $15-16 \%$, respectively.

\section{Experimental design}

Three Red Dane, three Guernsey and three HolsteinFriesian crossbred dairy cows, in mid-lactation (130 $\pm 19 \mathrm{~d}$ ) in the second trimester of pregnancy and average body condition score of 2.5 , were each fed the experimental diets in two experiments. In experiment 1, velvet bean, cowpea and commercial diets were fed to three dairy cows in a trial involving a $3 \times 3$ Latin square design. In experiment 2 , six dairy cows were each fed velvet bean, lablab and commercial diets in a trial involving a double $3 \times 3$ Latin square. Each animal was housed in a $3 \mathrm{~m} \times 5 \mathrm{~m}$ holding pen. Animals were given diets at $0.5 \mathrm{~kg}$ per litre of milk produced, fed in the morning and evening during milking time by dividing the daily allowance in to two equal parts (Gusha et al. 2013). Adjustment of the given diet was made weekly based on milk yield for each cow. In addition, each animal was given $3 \mathrm{~kg}$ maize silage daily. Maize stover and fresh clean water was given to each animal ad libitum. The duration of the experiment was $63 \mathrm{~d}$, divided into three experimental periods. The first $14 \mathrm{~d}$ were the adaptation period to the diet followed by $7 \mathrm{~d}$ of data collection on the same diet. The animals were treated for internal and external parasites before the experiment commenced.

\section{The $3 \times 3$ Latin square design}

A $3 \times 3$ Latin square design consists of three columns, three rows and three treatments, hence three explained sources of variability are defined (Kaps and Lamberson 2004). Each column and each row are a complete block of all treatments. In experiment 1 , it consisted of three animals $A, B$ and $C$ (columns), fed three diets $T_{1}, T_{2}$ and $T_{3}$ (treatments) consecutively over three feeding periods 1,2 and 3 (rows). Each animal received all treatments in consecutive periods. Precision is increased in an experiment through a simultaneous set of several Latin squares, as done in experiment 2 (Kaps and Lamberson 2004), as is illustrated in Figure 1. A Latin square design is used in on-farm trials to indicate animal responses to different treatments using repeated measures through multiple time periods, where animal numbers are limited (Quinn and Keough 2002).

\section{Data collection and analytical procedure}

Feed

Voluntary feed intake was computed as the difference between treatment diet quantity provided to the animal and quantity of feed refusal daily. Feed samples were collected at the beginning and at the end of each 21-day feeding period. Feed samples were dried in a forced air oven at $65{ }^{\circ} \mathrm{C}$ for $48 \mathrm{~h}$ to determine dry matter (DM) content. Chemical analysis was undertaken after grinding samples through a $1 \mathrm{~mm}$ sieve. Crude protein content in the feed was analysed by the Kjeldahl method (AOAC 1995). Crude fibre was determined according to Goering and van Soest (1970). Energy was determined by the bomb calorimetric method (AOAC 1995).

The ingredient composition, diet chemical composition and cost per kilogram of the diets were as shown in Table 1.

The feed ingredient cost for maize, soyabean meal, $16 \%$ Dairymeal (Pastulak) and vitamin premix was determined using prevailing market prices in Zimbabwe (current price as at July 2013 for experiment 1 and as at July 2014 for experiment 2). The ingredient cost of the respective forage-legume hays, grain, veld hay and maize stover was computed using actual production cost estimates from the farmers who produced the ingredients (production costs as at July 2013 for experiment 1 and as at July 2014 for experiment 2). The figures for an ingredient obtained from different farmers were averaged into a single figure proportionally by weight.

\section{Milk yield and quality}

Cows were hand-milked twice per day at 06:00 and 15:00. Each individual cow's daily milk yield was measured using a calibrated milk jar and recorded on milk weight sheets. Milk samples $(20 \mathrm{~mL})$ were collected daily during the seven-day data collection period by proportional pooling of morning and evening milking, and stored in sample bottles containing Bromopol (2-bromo-2-nitropropane1,3-diol + natamycin) preservative tablets to prevent spoilage before chemical analysis. Milk samples were analysed for protein, butterfat, lactose and total solids. Milk sampling was done following the procedures of Oliver et al. (2004). A Bentley DairySpec Combi 300 machine was used to analyse the milk for protein, butterfat, lactose and total solids.
Single Latin square

\begin{tabular}{cc|c|c}
\hline \multirow{2}{*}{$\begin{array}{c}\text { Rows } \\
\text { (periods) }\end{array}$} & $\mathrm{A}$ & $\mathrm{B}$ & $\mathrm{C}$ \\
\cline { 2 - 4 } & $\mathrm{T}_{1}$ & $\mathrm{~T}_{2}$ & $\mathrm{~T}_{3}$ \\
\hline 1 & $\mathrm{~T}_{3}$ & $\mathrm{~T}_{1}$ & $\mathrm{~T}_{2}$ \\
\hline 2 & $\mathrm{~T}_{2}$ & $\mathrm{~T}_{3}$ & $\mathrm{~T}_{1}$ \\
\hline 3 & \multicolumn{3}{|c}{}
\end{tabular}

\section{Double Latin square}

\begin{tabular}{|c|c|c|c|c|c|c|}
\hline \multirow{3}{*}{$\begin{array}{c}\text { Rows } \\
\text { (periods) }\end{array}$} & \multirow{2}{*}{\multicolumn{3}{|c|}{$\begin{array}{l}\text { Square } 1 \\
\text { Columns } \\
\text { (animals) }\end{array}$}} & \multirow{2}{*}{\multicolumn{3}{|c|}{$\begin{array}{l}\text { Square } 2 \\
\text { Columns } \\
\text { (animals) }\end{array}$}} \\
\hline & & & & & & \\
\hline & $A$ & $B$ & $C$ & $A$ & B & C \\
\hline 1 & $\mathrm{~T}_{1}$ & $\mathrm{~T}_{3}$ & $\mathrm{~T}_{2}$ & $\mathrm{~T}_{1}$ & $\mathrm{~T}_{2}$ & $\mathrm{~T}_{3}$ \\
\hline 2 & $\mathrm{~T}_{3}$ & $\mathrm{~T}_{2}$ & $\mathrm{~T}_{1}$ & $\mathrm{~T}_{2}$ & $\mathrm{~T}_{3}$ & $\mathrm{~T}_{1}$ \\
\hline 3 & $\mathrm{~T}_{2}$ & $\mathrm{~T}_{1}$ & $\mathrm{~T}_{3}$ & $\mathrm{~T}_{3}$ & $\mathrm{~T}_{1}$ & $\mathrm{~T}_{2}$ \\
\hline
\end{tabular}

A, B and C are the three different animals fed three different diets (T1, T2 and T3) over three consecutive feeding periods (1,2 and 3 ) 
Dietary cost benefit analysis

Dietary gross margin (DGM) was calculated as the difference between total income and dietary component cost of producing the diet. The DGM was computed using the following model as applied by Mburu et al. (2007) and Pengelly et al. (2004):

$$
D G M=M P * M V-F Q * F C
$$

where DGM represents dietary gross margin, MP represents the price of milk (US\$) per kilogram, MV represents the amount of milk produced by feeding a particular treatment diet, FQ represents the calculated amount of a particular treatment diet consumed to produce $\mathrm{MV}$, and FC represents the cost per kilogram of producing a particular treatment diet.

Cost of producing $1 \mathrm{~kg}$ of feed consisted of the sum cost of the dietary components and did not include other variable costs such as labour. The cost of producing $1 \mathrm{~kg}$ of milk is expressed as 'dietary' cost as it does not account for other variable costs such as veterinary cost, ad-libitum basal stover, silage, labour costs and costs associated with dry cows and heifers.

\section{Statistical analysis}

A repeated measures analysis of variance (ANOVA) was used to examine the effect of treatment, feeding period and animal on milk yield and milk composition using the General Linear Model procedure of the Statistical Analysis System software (SAS Institute 2012). Treatment means were compared using the Predicted Difference (pdiff) statistic (SAS Institute 2012). The model used was

$$
Y_{i j k}=\mu+T_{i}+P_{j}+C_{k}+e_{i j k}
$$

where $Y_{i j k}$ represents the (observation) response variable (Milk yield, protein, milk fat, lactose and total solids), $\mu$ is the overall mean/experimental mean, $T_{i}$ is the treatment effect where $i$ is a particular treatment, $P_{j}$ is the feeding period where $j$ is a particular feeding period, $C_{K}$ is the effect of animal where $k$ is a particular animal, and $e_{i j k}$ is the random residual with a distribution of $\mathrm{N} \sim(0 \sigma 2 \mathrm{E})$.

\section{Results}

\section{Diet intake}

There was no significant difference in diet intake $(P>0.05)$. The cows consumed the daily ration, which was divided into two equal portions, without any significant refusals (Table 2). However, it was noted that the animals on the velvet bean diet took longer to finish the diet during the first few days in the adaptation phase, which was recorded as refusals. The cows then readily consumed the diet thereafter. The calculated velvet been grain intake was $1.32 \mathrm{~kg} \mathrm{~d}^{-1}$.

\section{Milk yield and composition}

Significant differences in milk yield were observed across all diets. Specifically, milk yield was observed to be significantly greater compared to other diets $(P<0.05)$ for cows on a commercial diet and least on a cowpea diet in the two experiments (Tables 3 and 4), while cows on a lablab diet produced more milk than those on a velvet bean diet. There was a difference of more than $1 \mathrm{~L}$ in average daily milk yield between the highest-yielding diet (commercial diet) and the least-yielding diet (cowpea diet).

There were significant differences $(P<0.05)$ in milk composition across the diets. Milk fat was observed to be significantly highest $(P<0.05)$ in milk from cows fed a lablab diet and least in milk from cows fed a velvet bean diet. It can be noted that milk fat from cows fed a cowpea diet did not significantly differ to milk fat from cows fed a commercial diet, and was significantly higher than in milk from cows fed a velvet bean diet (Table 3). Milk protein did not significantly differ in milk from cows fed a commercial diet and those fed a lablab diet (Table 4), but was significantly higher than that of the other two treatments $(P<0.05)$. Within the forage diets, milk protein from cows fed a lablab diet was not significantly higher than milk protein from cows fed a velvet bean diet, but was significantly higher than that from cows fed a cowpea diet. Lactose content was significantly $(P<0.05)$ different among all treatment diets.

Table 2: Diet intake for dairy crossbred cows fed commercial, velvet bean and lablab diets in Goromonzi and Murehwa districts, Zimbabwe. Values within a column followed by different superscripts

\begin{tabular}{|c|c|c|c|c|}
\hline \multirow[b]{2}{*}{ Treatment } & \multirow{2}{*}{$\begin{array}{c}\text { Feed } \\
\text { provided } \\
\left(\mathrm{kg}^{-1} \mathrm{~d}\right)\end{array}$} & \multicolumn{2}{|c|}{ Refusals $\left(\mathrm{kg}^{-1} \mathrm{~d}\right)$} & \multirow{2}{*}{$\begin{array}{c}\text { Feed } \\
\text { intake } \\
\left(\mathrm{kg}^{-1} \mathrm{~d}\right)\end{array}$} \\
\hline & & Adaptation & $\begin{array}{c}\text { Data collection } \\
\text { period }\end{array}$ & \\
\hline Commercial diet $(n=9)$ & $3.2^{\mathrm{a}}$ & $0.0^{\mathrm{a}}$ & $0.0^{\mathrm{a}}$ & $3.2^{\mathrm{a}}$ \\
\hline Lablab diet $(n=6)$ & $3.1^{\mathrm{a}}$ & $0.0^{\mathrm{a}}$ & $0.0^{\mathrm{a}}$ & $3.1^{\mathrm{a}}$ \\
\hline Velvet bean diet $(n=9)$ & $3.1^{\mathrm{a}}$ & $0.1^{\mathrm{a}}$ & $0.0^{\mathrm{a}}$ & $3.1^{\mathrm{a}}$ \\
\hline Cowpea diet $(n=3)$ & $3.0^{a}$ & $0.0^{\mathrm{a}}$ & $0.0^{\mathrm{a}}$ & $3.0^{\mathrm{a}}$ \\
\hline Standard error & 0.001 & & & 0.001 \\
\hline
\end{tabular}
are significantly different at $P<0.05$

Table 3: Experiment 1: Milk yield and composition for dairy crossbred cows fed commercial, velvet bean and cowpea diets (each $n=3$ ) in Goromonzi and Murehwa districts, Zimbabwe. Values within a column followed by different superscripts are significantly different at $P<0.05$

\begin{tabular}{lccccc}
\hline Treatment & $\begin{array}{c}\text { Milk yield } \\
\left(\mathrm{kg} \mathrm{cow}^{-1} \mathrm{~d}^{-1}\right)\end{array}$ & $\begin{array}{c}\text { Protein } \\
(\%)\end{array}$ & $\begin{array}{c}\text { Milk fat } \\
(\%)\end{array}$ & $\begin{array}{c}\text { Lactose } \\
(\%)\end{array}$ & $\begin{array}{c}\text { Total } \\
\text { solids }(\%)\end{array}$ \\
\hline Commercial diet & $6.7^{\mathrm{a}}$ & $1.99^{\mathrm{a}}$ & $2.65^{\mathrm{a}}$ & $3.12^{\mathrm{a}}$ & $8.81^{\mathrm{a}}$ \\
Velvet bean diet & $6.1^{\mathrm{b}}$ & $1.82^{\mathrm{b}}$ & $1.92^{\mathrm{b}}$ & $2.72^{\mathrm{b}}$ & $7.37^{\mathrm{b}}$ \\
Cowpea diet & $5.6^{\mathrm{c}}$ & $1.67^{\mathrm{c}}$ & $2.60^{\mathrm{a}}$ & $2.56^{\mathrm{c}}$ & $7.47^{\mathrm{b}}$ \\
Standard error & 0.318 & 0.009 & 0.024 & 0.017 & 0.046 \\
\hline
\end{tabular}

Table 4: Experiment 2: Milk yield and composition for dairy crossbred cows fed commercial, lablab and velvet bean diets (each $n=6$ ) in Goromonzi and Murehwa districts, Zimbabwe. Values within a column followed by different superscripts are significantly different at $P<0.05$

\begin{tabular}{lccccc}
\hline Treatment & $\begin{array}{c}\text { Milk yield } \\
\left(\mathrm{kg} \mathrm{cow}^{-1} \mathrm{~d}^{-1}\right)\end{array}$ & $\begin{array}{c}\text { Protein } \\
(\%)\end{array}$ & $\begin{array}{c}\text { Milk fat } \\
(\%)\end{array}$ & $\begin{array}{c}\text { Lactose } \\
(\%)\end{array}$ & $\begin{array}{c}\text { Total } \\
\text { solids }(\%)\end{array}$ \\
\hline Commercial diet & $6.8^{\mathrm{a}}$ & $2.04^{\mathrm{a}}$ & $2.72^{\mathrm{a}}$ & $3.14^{\mathrm{a}}$ & $8.94^{\mathrm{a}}$ \\
Lablab diet & $6.4^{\mathrm{b}}$ & $2.01^{\mathrm{b}}$ & $2.97^{\mathrm{b}}$ & $3.08^{\mathrm{b}}$ & $7.58^{\mathrm{b}}$ \\
Velvet bean diet & $6.2^{\mathrm{c}}$ & $1.85^{\mathrm{c}}$ & $1.98^{\mathrm{c}}$ & $2.96^{\mathrm{c}}$ & $7.44^{\mathrm{b}}$ \\
Standard error & 0.176 & 0.006 & 0.026 & 0.005 & 0.048 \\
\hline
\end{tabular}


Highest milk lactose content was observed in milk from cows fed a commercial diet and least in milk from cows fed a cowpea diet. Total solids were observed to be significantly $(P<0.05)$ highest in milk from cows fed a commercial diet than in milk from the other diets. However, the total solids in milk from the forage legume diets was observed to be similar in both experiments (Tables 3 and 4 )

Milk yield was observed to be influenced by breed. Holstein-Fresian crossbred cows produced significantly higher milk yield than Red Dane and Guernsey crossbreds. There were an increase in milk yield as the experiment progressed (period). The cows also improved slightly in body condition score, improving by 0.5 grade points on average (Table 5).

\section{Economic returns}

Compared with the cowpea and commercial diet, the daily and monthly dietary gross income margins were higher for cows fed a velvet bean and lablab diet by $17 \%$ and $16.5 \%$, respectively. It follows that the dietary cost to produce $1 \mathrm{~L}$ of milk is higher and almost equivalent from cows fed a cowpea diet and a commercial diet by $28 \%$ and $23 \%$, respectively, compared with velvet bean and lablab diet-fed cows (Table 6). While the cowpea diet consumed was less $\left(2.8 \mathrm{~kg} \mathrm{~d}^{-1}\right)$ than the other forage diets (lablab $3.20 \mathrm{~kg} \mathrm{~d}^{-1}$ and velvet bean $3.05 \mathrm{~kg} \mathrm{~d}^{-1}$ ), it was noted that it was still more expensive.

\section{Discussion}

\section{Intake}

No difference in voluntary feed intake of the diets was observed. Diet intake is affected by anti-nutritional factors (ANFs), CP level and form (Madzimure et al. 2011). Velvet bean, lablab and cowpea contain ANFs that include tannins, phytic acid, saponins, cyanogenic glycosides, lectins and L-Dopa (in velvet bean only), which limit feed intake (Mapiye et al. 2006, 2007; Tuleun et al. 2008; Fathima et al. 2010). However, the study results indicate that inclusion of forage legumes in the diets did not have an effect on intake, which could have been a result of the low daily dietary inclusion quantities. Topps and Oliver (1993) report that besides the laxative effect observed if consumption levels of forage legume grain exceed $2 \mathrm{~kg} \mathrm{~d}^{-1}$ in cattle, no intake effect was observed. In this study, the average total dietary feed was $3 \mathrm{~kg} \mathrm{~d}^{-1}$, translating to a calculated velvet bean grain intake of $1.32 \mathrm{~kg} \mathrm{~d}^{-1}$.

Lazzarini et al. (2009), cited in Gusha et al. (2013), indicate that CP levels of below 6-8\% depress appetite and voluntary feed intake. In the present study the dietary $\mathrm{CP}$ level was $16 \%$, which further explains the intake pattern. The form in which forage is fed influences intake. According to Madzimure et al. (2011) tannin-rich feeds can be eaten in large quantities like any other non-tannin feed when dry rather than fresh. Drying of forages reduces the solubility of tannins, thereby affecting their ability to precipitate salivary proteins to cause an unpalatable astringent taste (Waghorn 2008). Tannin-rich forages used in the diets in this study are in the dried form, which might also explain the insignificant difference in intake of the diets. However, it was noted that cows initially took longer to finish the velvet bean diet. This could be due to the astringent taste that is associated with velvet bean due to tannin presence. However, the cows readily consumed the diet after a few days of adaptation.

Table 5: Comparison of milk yield and body condition score across breeds and period for dairy crossbred cows fed commercial, velvet bean, cowpea and lablab diets in Goromonzi and Murehwa districts, Zimbabwe. Values within a column followed by different superscripts are significantly different at $P<0.05$

\begin{tabular}{|c|c|c|c|c|c|c|c|}
\hline \multirow[b]{2}{*}{ Breed } & \multicolumn{2}{|c|}{ Period 1} & \multicolumn{2}{|c|}{ Period 2} & \multicolumn{2}{|c|}{ Period 3} & \multirow{2}{*}{$\begin{array}{l}\text { Average milk } \\
\text { yield }(\mathrm{kg})\end{array}$} \\
\hline & $\begin{array}{l}\text { Body condition } \\
\text { score }\end{array}$ & $\begin{array}{l}\text { Average milk } \\
\text { yield }(\mathrm{kg})\end{array}$ & $\begin{array}{l}\text { Body condition } \\
\text { score }\end{array}$ & $\begin{array}{c}\text { Average milk } \\
\text { yield }(\mathrm{kg})\end{array}$ & $\begin{array}{l}\text { Body condition } \\
\text { score }\end{array}$ & $\begin{array}{c}\text { Average milk } \\
\text { yield }(\mathrm{kg})\end{array}$ & \\
\hline Holstein-Friesian cross $(n=3)$ & 2.0 & $7.2^{\mathrm{a}}$ & 2.0 & $7.6^{\mathrm{a}}$ & 2.5 & $7.8^{\mathrm{a}}$ & $7.6^{a}$ \\
\hline Red Dane cross $(n=4)$ & 2.0 & $5.7^{\mathrm{b}}$ & 2.0 & $5.9^{\mathrm{b}}$ & 2.0 & $6.4^{\mathrm{b}}$ & $6.0^{\mathrm{b}}$ \\
\hline Guernsey cross $(n=2)$ & 2.5 & $4.7^{c}$ & 2.5 & $5.1^{c}$ & 2.5 & $5.5^{c}$ & $5.1^{c}$ \\
\hline Standard error & & 0.882 & & 0.667 & & 0.577 & 0.577 \\
\hline
\end{tabular}

Table 6: Economic analysis for dairy crossbred cows fed commercial, lablab, velvet bean and cowpea diets in Goromonzi and Murehwa districts, Zimbabwe

\begin{tabular}{|c|c|c|c|c|}
\hline Component & Commercial diet & Lablab diet & Velvet bean diet & Cowpea diet \\
\hline Milk yield $\left(\mathrm{kg} \mathrm{cow}^{-1} \mathrm{~d}^{-1}\right)$ & 6.7 & 6.4 & 6.1 & 5.6 \\
\hline Milk income per day (US\$) & 2.81 & 2.69 & 2.56 & 2.35 \\
\hline Calculated diet offered per day $(\mathrm{kg})^{\mathrm{a}}$ & 3.35 & 3.20 & 3.05 & 2.80 \\
\hline Diet cost per day ${ }^{b}$ & 1.41 & 1.06 & 0.92 & 1.12 \\
\hline Dietary net income per day (US\$) & 1.40 & 1.63 & 1.64 & 1.23 \\
\hline Dietary net income per 30 days (US\$) & 42.00 & 48.90 & 49.20 & 36.90 \\
\hline Dietary cost to produce $1 \mathrm{~L}$ milk $^{\mathrm{c}}$ & 0.21 & 0.16 & 0.15 & 0.20 \\
\hline
\end{tabular}

a Calculated diet offered per day was calculated at $0.5 \mathrm{~kg} \mathrm{~L}^{-1}$ milk produced in the previous week

${ }^{b}$ Diet cost is constituted of component feed elements costs excluding other costs such as labour

c Dietary cost to produce $1 \mathrm{~L}$ milk does not account for other variable costs, such as veterinary, ad-libitum basal stover, water, silage, labour and costs associated with dry cows and heifers 


\section{Milk yield and composition}

Holstein-Friesian crossbred animals gave a consistently higher milk yield across the periods when compared with Red Dane and Guernsey crossbreds (Table 5). This is consistent with literature where Holstein-Friesian were bred for high milk yields compared with Guernsey and Red Dane, which have lower milk yields with higher protein and fat content (Ngongoni et al. 2006). However, the average milk yield of all animals in the trial was lower than their breed yield potential. Costa et al. (2005) reported an average of $6.3 \mathrm{~L} \mathrm{~d}^{-1}$ milk yield for Holstein-Zebu crossed cows fed diets with graded levels of coffee pulp in Brazil. Madzimure et al. (2011) and Mashanda (2014) attribute the low milk yield in their studies to poor body condition, which is consistent with this study where the body condition of the animals was $2-2.5$ on average (Table 5). Table 4 indicates that the animals seemed to improve in body condition slightly as the study period progressed, but the cows remained in the poor body condition score-band of 2-3. Wattiaux (2005) and Mapekula et al. (2009) concur that cows that have poor body condition have reduced milk production due to lack of adequate reserves to mobilise for milk production. Ngongoni et al. (2006) states that in low-resource and low-input production systems, such as those prevalent in the smallholder sector, dairy cows perform below their genetic potential.

An increase in milk yield was observed as the experiment progressed. According to Heck et al., (2009), milk yield and quality is not only influenced by breed and feeding system, but also by physiological factors such as age and stage of lactation. Machuwe (2010) concurs that milk yield and quality is influenced by stage of lactation, parity, size of animal, feed construct, level of feeding and the body condition. Padekar and Bhoite (2002) cite that milk yield gradually increases post-partum and peaks at mid-lactation and gradually decreases towards parturition due to nutritional demands of the growing foetus. This is consistent with the study results (Table 5) where milk yield is increasing with period.

Several authors agree that milk yield tends to be affected by dietary protein content, which affects the amount of protein and energy available for milk synthesis (Ngongoni et al. 2009; Barde et al. 2010; Chakoma 2012). However, despite the diets in this study being isonitrogenous and isoenergetic, there were significant differences in milk yield. Differences in milk yield might be attributed to other dietary factors in the feeds that include ANFs. Work by Gwanzura et al. (2012) indicated that velvet bean has higher concentrations of both condensed and hydrolysable tannins than lablab, cowpea and sorghum. However, the study results indicate that average milk yield from cows fed a cowpea diet was lower than average milk from cows fed a velvet bean diet. Ayala-Burgos et al. (2003) and lyayi and Taiwo (2003) reported that velvet bean is an excellent source of fermentable nitrogen and energy to rumen microorganisms and compares favourably to soybean amino acid and mineral profile. Given the low daily intake levels of velvet bean (1.32 $\left.\mathrm{kg} \mathrm{d}^{-1}\right)$, the anti-nutritional effect of L-Dopa and tannins might have been significantly reduced in masking an effect on fermentable nitrogen and energy levels. This could explain why cows fed a velvet bean diet gave higher milk yields than those fed a cowpea diet. Work by Buwu (2014) indicated that lablab-based diets had higher in vitro organic matter and dry matter digestibility than velvet bean-based diets. This could explain how cows fed a lablab diet produced higher milk yields than those fed a velvet bean diet. In contrast, Murungweni et al. (2004) demonstrated that the use of a lablab hay supplement resulted in milk yield increases slightly less than those obtained through the use of velvet bean. Mapiye et al. (2007) explains this variability by differences in agronomic and edaphic factors that affect the nutrient quality of the forages.

Milk from cows fed a commercial diet and lablab-based diet was significantly higher in milk protein than from cows fed velvet bean- and cowpea-based diets. According to Hulár and Brand (1993), increasing forage content of diets increases milk fat and suppresses milk protein. This could explain the higher milk protein in milk from cows fed a commercial diet than those on forage-based diets. Ayala-Burgos et al. (2003) reported that when forage legumes, such as velvet bean, are used in stock-feed, the grain is readily available in the rumen hence can be considered an excellent source of fermentable nitrogen to the rumen microorganisms. However, ANFs present in velvet bean seeds, such as trypsin and chymotrypsin inhibitors, reduce protein digestibility and induce pancreatic hypertrophy and hyperplasia (Kumar 1991). This could further explain the lower milk protein from cows fed a velvet bean-based diet compared with a lablab-based diet that contained hay.

Fat content is affected by the acetate to propionate ratio. Milk fat was significantly different across all diets, with milk from cows on a velvet bean diet being the lowest and on a lablab diet being the highest. Milk fat content is influenced by fat, grain content and neutral detergent fibre content in the diet (Jenkins and McGuire 2006; Rutkowska et al. 2012). High grain content depresses milk fat due to inadequate rumen production of acetate and butyrate for the synthesis of milk fat. Jenkins and McGuire (2006) further explain that propionate from grain stimulates insulin concentration, which redirects metabolites away from mammary tissue. This can explain the low milk fat from cows fed a velvet bean-based diet in this study that is high in velvet bean seeds. High neutral detergent fibre from hay-rich diets stimulates high milk fat percentage. Increasing forage content of diets increases milk fat and suppresses milk protein, which is consistent with the results in this study (Tables 3 and 4) where milk fat from cows fed forage-based diets was comparable to milk fat from cows fed a commercial diet.

According to Jenkins and McGuire (2006), lactose is not affected by dietary variances except in extreme cases. Lactose content is affected by physiological variability of the animal, nutritional status, stage of lactation, season of the year, age and quantity of milk produced. Significant differences were observed in the lactose content of milk in this study. Differences observed could have resulted from significant differences in milk quantities observed in this study. However, Kittivachra et al. (2007) indicate that lactose is to some extent affected by nutrition. Kittivachra et al. (2007) further indicate that lactose synthesis seems to be supported by high-fibre diets through manipulation of the propionate-acetate balance. 
As milk total solids is a culmination of milk fat, lactose and protein, total solids vary depending on the predominant factor affected of these three. Holmes and Wilson (1984) indicate that total solids follow protein and fat trends as affected by stage of lactation implying milk quantity. In this study milk from cows fed forage-based diets had lower total solids than milk from cows fed a commercial diet.

Tables 3 and 4 indicate lower milk composition content than observed in other studies (Volpelli et al. 2010; Gusha et al. 2013). This is consistent with Machuwe (2010) who cites that milk yield and quality is influenced by level of feeding and the body condition. Cows with poor body condition produce lower milk yields with inferior quality. Lactating cows that consume less than $3 \%$ of their body weight in feed DM often produce low milk yield with low milk component percentages. In most smallholder farming areas, during the drier months of the year, there is poor feed quantity and quality. This may explain the poor body condition score and related milk yields and composition.

\section{Economic returns}

Velvet bean- and lablab-based diets have significantly higher dietary net income and lower production costs per litre of milk produced than a commercial diet. This is due to the lower cost of producing these forage-based diets. Similar results have been observed by several authors (Murungweni et al. 2004; Mupenzi et al. 2009; Olafadehan and Adewumi 2010; Chakoma 2012; Omer et al. 2012; Gusha et al. 2013). These authors concur that cheap high-nitrogen sources can improve the economic profitability of smallholder dairy. According to Gusha et al. (2013) farmers who reduce use of commercially prepared supplements improve their income by nearly $50 \%$. Murungweni (2004) concurs by indicating that using ley legumes has been shown to increase profits by over $300 \%$ in smallholder dairy systems.

In smallholder dairy systems, where feed costs account for $70 \%$ of production costs, feed is the major factor limiting viability. During the feed gap in the drier months of the year, when feed quantity and quality is poor, it becomes necessary to supplement. Supplementing using commercial supplements, which are more than $20 \%$ higher in cost, reduces smallholder dairy viability. Forage legumes not only reduce feed costs significantly, but have good agronomic attributes suitable for smallholder farming systems, which include soil amelioration properties. Lablab and velvet bean are adapted and suitable for production in Zimbabwe at the smallholder farming system level. The present study indicated an improvement in the body condition score as well as an increase in milk yield across all diets, as the experiment progressed. This demonstrates the potential of forage legumes to contribute to livestock production in the smallholder dairy sector. Forage legumes have the potential to contribute to smallholder dairy productivity at a reduced cost, contributing to viability and availability of quality supplements during the drier months of the year, which usually coincide with poor feed quantity and quality. The contribution of smallholder dairy to household income and economic food security can potentially be improved through sustainable feeding strategies that enhance performance of smallholder dairy systems.

\section{Conclusion}

Use of forages can be a cost-effective feed-level intervention to optimise income in small-scale dairy systems by reducing the cost of producing each litre of milk. Use of low-cost farm-produced forages as alternative feed for resource-poor smallholder farmers enhances the economic viability of the dairy business.

\section{References}

Arriaga-Jordán CM, Albarrán-Portillo B, Espinoza-Ortega A, GarcíaMartínez A, Castelán-Ortega OA. 2002. On-farm comparison of feeding strategies based on forages for small-scale dairy production systems in the highlands of central Mexico. Experimental Agriculture 38: 375-388.

AOAC (Association of Official Analytical Chemists). 1995. Official methods of analysis (16th edn). Arlington: AOAC International.

Ayala-Burgos AJ, Herrera-Diaz PE, Castillo-Caamal JB, RosadoRivas RM, Osornio-Munoz L, Castillo-Caamal AM. 2003. Rumen degradability and chemical composition of velvet bean (Mucuna spp.) grain and husk. Tropical and Subtropical Agroecosystems 1: $71-75$

Barde RE, Aya VE, Ari MM, Musa M, Yakubu A. 2010. Performance of West African Dwarf (WAD) goats fed urea-treated maize offal as supplement to natural herbage. Nigerian Veterinary Journal 31: 219-223.

Buwu V. 2014. Intensification of smallholder beef production systems using tropical forage legumes. MSc thesis, University of Zimbabwe, Harare, Zimbabwe.

Chakeredza S, Akinnifesi FK, Ajayi OC, Gudeta S, Mngomba S, Gondwe FMT. 2008. A simple method of formulating least-cost diets for smallholder dairy production in sub-Saharan Africa. African Journal of Biotechnology 7: 2925-2933.

Chakoma Cl. 2012. Sustainable forage production strategies for small scale livestock production in Zimbabwe. International Journal of Agriculture Innovations and Research 1: 85-90.

Chinogaramombe GNC, Muchenje V, Mapiye C, Ndlovu T, Chimonyo N, Musemwa L. 2008. Challenges for improving smallholder dairy production in the semiarid areas of Zimbabwe. Livestock Research and Rural Development 20(3): Art. \#34.

Costa TAA, Neves PM, Tavares MR, Chaves ML. 2005. Performance of Holstein-Zebu cows under partial replacement of corn by coffee hulls. Scientia Agricola 62: 95-101.

Department of Livestock Production and Development. 2011. Dairy services statistics. Harare: Ministry of Agriculture, Mechanisation and Irrigation Development, Zimbabwe.

Department of Livestock Production and Development. 2014. National Livestock Development Policy Draft. Harare: Ministry of Agriculture, Mechanisation and Irrigation Development, Zimbabwe.

Fathima KR, Tresina-Soris P, Mohan VR. 2010. Nutritional and anti-nutritional assessment of Mucuna pruriens (L.) DC var. pruriens, an underutilized tribal pulse. Advances in Bioresearch 1: 79-89.

García-Martínez A, Albarrán-Portillo B, Castelán-Ortega OA, Espinoza-Ortega A, Arriaga-Jordán CM. 2009. Urea treated maize straw for small-scale dairy systems in the highlands of central Mexico. Tropical Animal Health and Production 41: 1487-1494.

Gerber PJ, Steinfeld H, Henderson B, Mottet A, Opio C, Dijkman J, Falcucci A, Tempio G. 2013. Tackling climate change through livestock: a global assessment of emissions and mitigation opportunities. Rome: Food and Agriculture Organization of the United Nations.

Goering HK, van Soest PJ. 1970. Forage fiber analyses (apparatus, 
reagents, procedures, and some applications). Agriculture Handbook no. 379. Washington, DC: US Department of Agriculture, Agricultural Research Service.

Gusha J, Manyuchi CR, Imbayarwo-Chikosi VE, Hamandishe VR, Katsande S, Zvinorova PI. 2013. Production and economic performance of F1-crossbred dairy cattle fed non-conventional protein supplements in Zimbabwe. Tropical Animal Health and Production 46: 1257-1263.

Gwanzura T, Ng'ambi JW, Norris D. 2012. Nutrient composition and tannin contents of forage sorghum, cowpea, lablab and mucuna hays grown in Limpopo province of South Africa. Asian Journal of Animal Sciences 6: 256-262.

Holmes CW, Wilson GF. 1984. Milk production from pasture. Wellington: Butterworths.

Hove L, Franzel S, Moyo PS. 2003. Farmer experiences in the production and utilisation of fodder trees in Zimbabwe: Constraints and opportunities for increased adoption. Tropical Grasslands 37: 279-283.

Hulár I, Brand A. 1993. Nutritional factors affecting milk quality, with special regard to milk protein: a review. Acta Veterinaria Hungarica 41: 11-32.

Iyayi EA, Taiwo VO. 2003. The effect of diets incorporating Mucuna (Mucuna pruriens) seed meal on the performance of laying hens and broilers. Tropical and Subtropical Agroecosystems 1: 239-246.

Jenkins TC, McGuire MA. 2006. Major advances in nutrition: impact on milk composition. Journal of Dairy Science 89: 1302-1310.

Kaps M, Lamberson WR. 2004. Biostatistics for animal science. Wallingford: CABI Publishing.

Kittivachra R, Sanguandeekul R, Sakulbumrungsil R, Phongphanphanee P. 2007. Factors affecting lactose quantity in raw milk. Songklanakarin Journal of Science and Technology 29: 937-943.

Kumar R. 1991. Anti-nutritional factors, the potential risks of toxicity and methods to alleviate them. Journal of Animal Feed Science and Technology 30: 145-160.

Lazzarini I, Detmann E, Sampaio CB, Paulino MF, Filho SCV, de Souza MA, Oliveira FA. 2009. Intake and digestibility in cattle fed low-quality tropical forage and supplemented with nitrogenous compounds. Revista Brasileira de Zootecnia 38: 2021-2030.

Maasdorp BV, Jiri O, Temba E. 2004. Contrasting adoption, management, productivity and utilization of mucuna in two different smallholder farming systems in Zimbabwe. In: Whitbread AM, Pengelly BC (eds), Tropical legumes for sustainable farming systems in southern Africa and Australia. ACIAR Proceedings no. 115. Canberra: Australian Centre for International Agricultural Research. pp 154-163.

Machuwe J. 2010. Effects of substituting cassava based silage on Holstein cows on milk yield, composition and strongia worm egg count (WEC). MSc thesis, University of Zimbabwe, Harare, Zimbabwe.

Madzimure J, Musimurimwa C, Chivandi E, Gwiriri L, Mamhare E. 2011. Milk yield and quality in Guernsey cows fed cottonseed cake-based diets partially substituted with baobab (Adansonia digitata L.) seed cake. Tropical Animal Health and Production 43: 77-82.

Manyawu GJ, Thorne P, Moyo S, Omore A, Lukuyu B, Katjiuongua H, Wright I, Chakoma I. 2013 Application of the principles of sustainable intensification (SI) on smallholder dairy farming in eastern and southern Africa. Paper presented at the 9th African Dairy Conference and Exhibition, Harare, Zimbabwe, 24-26 September 2013. Available at http://www.slideshare.net/ILRI/9thafricandairyconf-manyawu [accessed 24 November 2014].

Mapekula M, Chimonyo M, Mapiye C, Dzama K. 2009. Milk production and calf rearing practices in the smallholder areas in the Eastern Cape province of South Africa. Tropical Animal Health and Production 41: 1475-1485.
Mapiye C, Foti R, Mwale M, Chikumba N, Poshiwa X, Chivuraise C, Mupangwa JF. 2006. Constraints to adoption of forage and browse legumes by smallholder dairy farmers in Zimbabwe. Livestock Research for Rural Development 18(12): Art. \#175.

Mapiye C, Mwale M, Mupangwa JF, Mugabe PH, Poshiwa X, Chikumba N. 2007. Utilisation of ley legumes as livestock feed in Zimbabwe. Tropical Grasslands 41: 84-91.

Mashanda P. 2014. Potential of Mucuna pruriens and Vigna unguiculata as replacement feed for commercial concentrates in a smallholder dairy enterprise. MSc thesis, University of Zimbabwe, Harare, Zimbabwe.

Mburu LM, Gitu KW, Wakhungu JW. 2007. A cost-benefit analysis of smallholder dairy cattle enterprises in different agro-ecological zones in Kenya highlands. Livestock Research for Rural Development 19(2): Art. \#95.

Moran J. 2005. Tropical dairy farming: feeding management for small holder dairy farmers in the humid tropics. Collingwood: Land Links.

Mugwira LM, Nyamangara J. 1998. Organic carbon and plant nutrients in soils under maize in Chinamhora Communal area, Zimbabwe. In: Bergstrom L, Kirchman H (eds), Carbon and nutrient dynamics in natural and tropical ecosystems. Wallingford: CAB International. pp 15-22.

Mupenzi M, Karenzi E, Kanani T, Lussa Birasa A. 2009. Uses of supplement levels of Stylosanthes scabra (Stylo) leaf meal on milk yield of Ankole cows. Livestock Research for Rural Development 21(5): Art. \#63.

Murungweni EC, Mabuku O, Manyawu GJ. 2004. Mucuna, lablab and paprika calyx as substitutes for commercial protein sources used in dairy and pen-fattening diets by smallholder farmers of Zimbabwe. In: Whitbread AM, Pengelly BC (eds), Tropical legumes for sustainable farming systems in southern Africa and Australia. ACIAR Proceedings no. 115. Canberra: Australian Centre for International Agricultural Research. pp 126-135.

Ngongoni NT, Mapiye C, Mwale M, Mupeta B. 2006. Factors affecting milk production in the smallholder dairy sector of Zimbabwe. Livestock Research for Rural Development 18(5): Art. \#72.

Ngongoni NT, Mapiye C, Mwale M, Mupeta B, Chimonyo M. 2009. Sunflower based rations for small-medium milk producing dairy cows. Pakistan Journal of Nutrition 8: 377-383.

Nyamapfene KW. 1991. Soils of Zimbabwe. Harare: Nehanda Publishers.

Olafadehan OA, Adewumi MK. 2010. Milk yield and composition of pre-partum bunaji cows supplemented with agro-industrial by-products in smallholder dairy production systems. Tropical and Subtropical Agroecosystems 12: 557-564.

Oleredi BJ, Ajayi G. 2005. Replacement of groundnut cake and maize with Falderbia albida Goa in the diets of broiler chicks. Bulletin of Animal Health and Production in Africa 53: 97-105.

Oliver SP, Hogan JS, Jayarao BM, Owens WE. 2004. Microbiological procedures for the diagnosis of bovine udder infection and determination of milk quality (4th edn). Verona, WI: National Mastitis Council.

Omer HAA, Ali FAF, Gad SM. 2012. Replacement of clover hay by biological treated corn stalks in growing sheep rations. Journal of Agricultural Science 4: 257-264.

Osman ROM. 2014. SADC trade with the European Union from a preferential to a reciprocal modality. South African Journal of Economics 83: 23-40.

Pengelly BC, Whitbread A, Mazaiwana PR, Mukombe N. 2004. Tropical forage research for the future - better use of research resources to deliver adoption and benefits to farmers. In: Whitbread AM, Pengelly BC (eds), Tropical legumes for sustainable farming systems in southern Africa and Australia. ACIAR Proceedings no. 115. Canberra: Australian Centre for International Agricultural Research. pp 28-37. 
Quinn G, Keough M. 2002. Experimental design and data analysis for biologists. Cambridge: Cambridge University Press.

Ross SA, Mizeck GG, Chagunda AN, Cairistiona FE, Topp A, Ennos R. 2014. Effect of cattle genotype and feeding regime on greenhouse gas emissions intensity in high producing dairy cows. Livestock Science 170: 158-171

Rutkowska J, Adamska A, Bialek M. 2012. Fatty acids profile of the milk of cows reared in the mountain region of Poland. Journal of Dairy Research 79: 469-476.

SAS Institute. 2012. SAS/STAT user's guide (9th edn). Cary: SAS Institute.

Siddhuraju P, Becker K. 2001. Effect of various domestic processing methods on antinutrients and in vitro protein and starch digestibility of two indigenous varieties of Indian tribal pulse, Mucuna pruriens var. utilis. Journal of Agriculture and Food Chemistry 49: 3058-3067.

Thornton PK, Herrero M. 2010. Potential for reduced methane and carbon dioxide emissions from livestock and pasture management in the tropics. Proceedings of the National Academy of
Sciences of the USA 107: 19667-19672.

Topps J, Oliver J. 1993. Animal foods of central Africa. Zimbabwe Agricultural Journal 2: 67-68 (revised edition).

Tuleun CD, Carew SN, Ajiji I. 2008. Feeding value of velvet beans (Mucuna utilis) for laying hens. Livestock Research for Rural Development 20(5): Art. \#81.

Volpelli LA, Comellini M, Masoero F, Moschini M, Lo Fiego DP, Scipioni R. 2010. Faba beans (Vicia faba) in dairy cow diet: effect on milk production and quality. Italian Journal of Animal Science 9(1): e27.

Waghorn G. 2008. Beneficial and detrimental effects of dietary condensed tannins for sustainable sheep and goat productionprogress and challenges. Animal Feed Science and Technology 147: 116-139.

Wattiaux MA. 2005. Body condition scores. In: Dairy Essentials. Reproduction and Genetic Selection. Madison: Babcock Institute for International Dairy Research and Development, University of Wisconsin-Madison. 